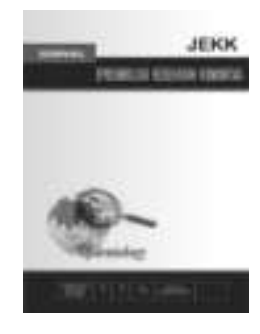

\title{
Hubungan Karakteristik Demografi, Faktor Keselamatan Dan Kesehatan Kerja (K3) Dan Lingkungan Terhadap Kejadian Leptospirosis (Studi Pada Pekerja Sektor Informal di Kota Semarang Tahun 2013-2016)
}

\author{
Maria Ulfah $^{*}$, Anies $^{* *}$, Mateus Sakundarno ${ }^{* * *}$, Henry Setyawan ${ }^{* * *}$, Ari Suwondo ${ }^{* * *}$ \\ "PT Electroconsult Palembang, ${ }^{* *}$ Fakultas Kedokteran Universitas Diponegoro \\ ${ }^{* * *}$ Fakultas Kesehatan Masyarakat Universitas Diponegoro
}

\begin{abstract}
Background: Leptospirosis is a disease caused by pathogenic bacteria called Leptospira, which is transmitted directly or indirectly. There were many of Leptospirosis study. However, the relation between demographic characteristic, occupational health and safety, and environmental factors foccusing on the workers of informal sectors was unclear. The objectives of study were to measure the association between demographic characteristics, Occupational, Health and Safety, and environmental factors with Leptospirosis in the workers of informal sectors.

Methods: An observational study with case-control design. Popupation of the study were all of workers of the informal sectors in Semarang City, it is including, but not limited to farmers, cleaning worker, laborers (farming, construction, handyman) and traditional market worker. Sample of the study were 82 persons, consist of 41 cases and 41 controls. Sample were taking by consecutive sampling. Data analysis perform by univariant, bivariant, and multivariant.

Results: The main risk factors were age ( $18-40$ years old) $\mathrm{p}=0,017$; aOR=42,22; 95\% CI=1,96- 906,55; Gender (male) $\mathrm{p}=0,017$; aOR=37,01, 95\%CI=1,9- 718,6; history of open wound during working $\mathrm{p}=0,042 ; \mathrm{aOR}=10,85 ; 95 \% \mathrm{CI}=1,08-108,24$; home sanitation (poor, with score $<60 \%$ ) $\mathrm{p}=0,025$; $\mathrm{aOR}=25,25 ; 95 \% \mathrm{CI}=1,5-423,3$; and history of contact with the source of infection $\mathrm{p}=0,003 ; \mathrm{aOR}=56,98 ; 95 \% \mathrm{CI}=3,8-849,2$.
\end{abstract}

Conclusion: Demographic characteristics, Occupational, Health and Safety, and environmental factors were associated with Leptospirosis.

Key words: Leptospirosis, occupational health and safety, environmental, workers of informal sectors

*Penulis korespondensi : blogmaria85@gmail.com 


\section{Pendahuluan}

Leptospirosis adalah penyakit infeksi yang disebabkan oleh bakteri patogen yang disebut Leptospira, yang ditularkan baik secara langsung maupun tidak. $^{1,2}$ Kasus Leptospirosis di Jawa Tengah pada tahun 2011 dilaporkan (184 kasus, $\quad C F R=17,93 \%)$, meningkat dibanding tahun 2010 (133 kasus, $C F R=10,53 \%$ ). Sebanyak $38,04 \%$ kasus pada tahun 2011 tersebut dilaporkan terjadi di Kota Semarang. ${ }^{3}$ Berdasarkan persebarannya, kasus Leptospirosis di Provinsi Jawa Tengah selama 11 tahun (2002-2012) cenderung meluas.

Berdasarkan endemisitas wilayah terdapat 14 wilayah endemis Leptospirosis, dengan kasus tertinggi di Kota Semarang. ${ }^{4}$ Leptospirosis Kota Semarang tahun 2015 (Incidence Rate $(I R)=3,40$ per 100.000 jiwa, $C F R=14,29 \%$ ). Berdasarkan persebarannya, kasus Leptospirosis di Kota Semarang semakin meluas, yaitu dari 81 kasus pada 21 puskesmas (2012) menjadi 71 kasus pada 23 puskesmas (2013) dan meningkat menjadi 75 kasus pada 28 Puskesmas (2014). Berdasarkan jenis pekerjaan sebanyak 38\% kasus Leptospirosis (2015) bekerja pada sektor informal. $^{5-7}$ Tenaga kerja sektor informal adalah tenaga kerja yang bekerja pada segala jenis pekerjaan tanpa ada perlindungan negara dan atas usaha tersebut tidak dikenakan pajak. Pekerja sektor informal seperti buruh dianggap sebagai pekerja kasar (blue collar) sebagai pekerja pada pekerjaan yang mengandalkan kekuatan fisik. ${ }^{8}$

Penelitian mengenai Leptospirosis pada manusia sudah banyak dilakukan, tetapi hubungan antara karakteristik demografi, K3 dan lingkungan yang terfokus pada pekerja sektor informal sebagai faktor risiko Leptospirosis sejauh ini masih belum jelas dan jarang dilakukan. Tujuan penelitian ini adalah untuk mencari hubungan antara karakteristik demografi, K3 dan lingkungan pada pekerja sektor informal di Kota Semarang.

\section{Metode}

Penelitian ini adalah penelitian observasional analitik dengan rancangan penelitian kasus kontrol. ${ }^{9}$ Populasi kasus adalah seluruh penderita Leptospirosis yang terdaftar pada laporan Dinas Kesehatan Kota Semarang selama rentang waktu 2013-2016 yang bekerja pada sektor informal. Jenis pekerjaan pada sektor informal dibatasi sesuai dengan faktor risiko paparan, yaitu petani, peternak, pekerja kebun, petugas kebersihan, buruh (buruh tani, buruh serabutan, buruh bangunan, buruh cuci), pekerja di pasar tradisional. Populasi Kontrol adalah seluruh pekerja sektor informal yang tidak sakit Leptospirosis, tidak memperlihatkan ciri-ciri umum terserang Leptospirosis dan atau demam (selama $2 \mathrm{x}$ masa inkubasi terpanjang/2x30 hari).

Pengambilan sampel dirinci dalam tahapan sebagai berikut: (1) Pengumpulan data kasus Leptospirosis tahun 2016-2013 berdasarkan puskesmas. (2) Penelusuran dan konfirmasi data kasus ke setiap puskesmas dengan mengumpulkan dokumen PE. (3) Pengumpulan data pasien PTM konfirmasi data untuk kontrol dengan data rekam medis pada simpus puskesmas. Analisis data menggunakan SPSS versi 20. Analisis bivariat dengan uji chi square, nilai ditentukan dengan OR (odds ratio) pada confidence interval (CI) sebesar 95\% dan $\alpha=0,05$. Analisis multivariat untuk mengendalikan pengaruh variabel confounding dan mengetahui pengaruh variabel bebas yang paling dominan terhadap variabel terikat yang dilakukan secara bersama dengan menggunakan uji regresi logistik metode backward $L R$ pada $C I=95 \%$. $^{10}$

\section{Hasil}

Probabilitas faktor risiko kejadian Leptospirosis pada pekerja sektor informal, pemodelan variabel bebas dan confounding berdasarkan rumus probability event disajikan pada Tabel 13. 
Tabel 1. Distribusi kasus dan kontrol serta hasil analisis bivariat

\begin{tabular}{|c|c|c|c|c|c|c|c|}
\hline \multirow{2}{*}{ Variabel } & \multicolumn{2}{|c|}{ Kasus } & \multicolumn{2}{|c|}{ Kontrol } & \multirow{2}{*}{$95 \% \mathrm{CI}$} & \multirow{2}{*}{ OR } & \multirow{2}{*}{$\mathrm{P}$} \\
\hline & $\mathrm{n}$ & $(\%)$ & $\mathrm{n}$ & $(\%)$ & & & \\
\hline \multicolumn{8}{|l|}{ Kategori Umur } \\
\hline umur 18- 40 tahun & 12 & 29,3 & 5 & 20,7 & & & \\
\hline umur $>40$ tahun & 29 & 70,7 & 36 & 87,8 & $0,1-1,06$ & 0,33 & 0,057 \\
\hline Jumlah & 41 & 100,0 & 41 & 100,0 & & & \\
\hline \multicolumn{8}{|l|}{ Jenis Kelamin } \\
\hline Laki-laki & 33 & 80,5 & $\overline{25}$ & 61,0 & & & \\
\hline Perempuan & 8 & 19,5 & 16 & 39,0 & $0,9-7,1$ & 2,64 & 0,052 \\
\hline Jumlah & 41 & 100,0 & 41 & 100,0 & & & \\
\hline \multicolumn{8}{|l|}{ Kategori Pendidikan } \\
\hline Rendah $(<9$ tahun $)$ & $\overline{21}$ & 51,2 & $\overline{19}$ & 46,3 & & & \\
\hline Tinggi (> 9 tahun) & 20 & 48,8 & 22 & 53,7 & $0,5-2,9$ & 1,21 & 0,659 \\
\hline Jumlah & 41 & 100,0 & 41 & 100,0 & & & \\
\hline \multicolumn{8}{|l|}{ Kategori Perilaku } \\
\hline Buruk (Skor <60,0\%) & 24 & 58,5 & 3 & 7,3 & & & \\
\hline Baik (Skor $>60,1 \%)$ & 17 & 41,5 & 38 & 92,7 & $4,7-67,6$ & 17,88 & $<0,0001$ \\
\hline Jumlah & 41 & 100,0 & 41 & 100,0 & & & \\
\hline \multicolumn{8}{|l|}{ Penggunaan APD } \\
\hline Tidak & 39 & 95,1 & $\overline{31}$ & $\overline{75,6}$ & & & \\
\hline $\mathrm{Ya}$ & 2 & 4,9 & 10 & 24,4 & $1,2-30,8$ & 6,29 & 0,010 \\
\hline Total & 41 & 100,0 & 41 & 100,0 & & & \\
\hline \multicolumn{8}{|l|}{ Lama Kerja } \\
\hline$>8$ jam perhari & 5 & 12,2 & $-\overline{1}$ & $\overline{2,4}$ & & & \\
\hline$<8$ jam perhari & 36 & 87,8 & 40 & 97,5 & $0,6-49,8$ & 5,56 & 0,210 \\
\hline Jumlah & 41 & 100,0 & 41 & 100,0 & & & \\
\hline \multicolumn{8}{|c|}{ Riwayat Luka saat bekerja } \\
\hline $\mathrm{Ya}$ & 27 & 65,9 & 13 & 31,7 & & & \\
\hline Tidak & 14 & 34,1 & 28 & 68,3 & $1,6-10,4$ & 4,15 & 0,002 \\
\hline Jumlah & 41 & 100,0 & 41 & 100,0 & & & \\
\hline \multicolumn{8}{|l|}{ Kondisi Sanitasi Rumah } \\
\hline Buruk (Skor <60\%) & 36 & 87,8 & 9 & 22,0 & & & \\
\hline Baik $($ skor $>60 \%)$ & 5 & 12,2 & 32 & 78,0 & $7,7-84,3$ & 25,60 & $<0,0001$ \\
\hline Jumlah & 41 & 100,0 & 41 & 100,0 & & & \\
\hline \multicolumn{8}{|c|}{ Kategori Kondisi Sanitasi tempat kerja } \\
\hline Buruk (Skor $<51,0 \%)$ & 36 & 87,8 & $\overline{11}$ & 26,8 & & & \\
\hline Baik (Skor $>=52,0 \%)$ & 5 & 12,2 & 30 & 73,2 & $6,1-62,1$ & 19,63 & $<0,0001$ \\
\hline Jumlah & 41 & 100,0 & 41 & 100,0 & & & \\
\hline \multicolumn{8}{|l|}{ Tikus di tempat kerja } \\
\hline $\mathrm{Ya}$ & 38 & 92,7 & $\overline{11}$ & 46,3 & & & \\
\hline Tidak & 3 & 7,3 & 3 & 53,7 & $3,8-55,2$ & 14,66 & $<0,0001$ \\
\hline Jumlah & 41 & 100,0 & 41 & 100,0 & & & \\
\hline \multicolumn{8}{|c|}{ Riwayat Kontak dengan sumber infeksi } \\
\hline Ya & 37 & 90,2 & 7 & 17,1 & & & \\
\hline Tidak & 4 & 9,8 & 34 & 82,9 & $12,0-167,1$ & 44,92 & $<0,0001$ \\
\hline Jumlah & 41 & 100,0 & 41 & 100,0 & & & \\
\hline
\end{tabular}


Tabel 2. Hasil Pemodelan Akhir Variabel Bebas dan Variabel Confounding

\begin{tabular}{|c|c|c|c|c|c|}
\hline No & Faktor Risiko & Koefisien B & $95 \% \mathrm{CI}$ & $\mathrm{aOR}$ & $\mathrm{p}$ \\
\hline 1 & $\begin{array}{l}\text { Umur Desasa } \\
(18-40 \text { tahun })\end{array}$ & 3,743 & $1,96-906,55$ & 42,22 & 0,017 \\
\hline 2 & Jenis Kelamin & 3,661 & $1,907-718,6$ & 37,01 & 0,017 \\
\hline 3 & $\begin{array}{l}\text { Riwayat Luka } \\
\text { saat Bekerja }\end{array}$ & 2,384 & $1,08-108,24$ & 10,85 & 0,042 \\
\hline 4 & $\begin{array}{l}\text { Kondisi Sanitasi } \\
\text { Rumah }\end{array}$ & 3,229 & $1,507-423,3$ & 25,25 & 0,025 \\
\hline 5 & $\begin{array}{ll}\text { Riwayat } & \text { Kontak } \\
\text { dengan } & \text { sumber } \\
\text { infeksi } & \end{array}$ & 4,043 & $3,824-849,2$ & 56,98 & 0,003 \\
\hline & Constant & $-9,513$ & & & \\
\hline
\end{tabular}

Tabel 3. Probability event Leptospirosis pada Pekerja Sektor Informal menurut Variabel Independen dan Variabel Confounding

\begin{tabular}{lll}
\hline No & Faktor Risiko & Probabilitas (\%) \\
\hline 1 & Tanpa faktor risiko & 0,006 \\
2 & Umur 18-40 tahun & 0,323 \\
3 & Jenis kelamin laki-laki & 0,284 \\
4 & Riwayat Luka pada saat bekerja & 0,084 \\
5 & Kondisi Sanitasi Rumah & 0,194 \\
6 & Kondisi Sanitasi Tempat kerja & 0,073 \\
7 & Riwayat Kontak dengan sumber infeksi & 0,435 \\
8 & 2 Variabel Independen (R.Luka, dan R.kontak) dan tanpa & 4,457 \\
& variabel counfonding & \\
9 & 3 Variabel confounding (Umur,JK,Sanitasi rumah), tanpa 3 & 74,322 \\
& faktor risiko & \\
10 & Dengan semua variabel terbukti (umur+JK+R.Luka+Sanitasi & \\
& rumah+Sanitasi tempat kerja+R.kontak dengan sumber & 99,942 \\
& infeksi & \\
\hline
\end{tabular}

\section{Pembahasan}

Lokasi penelitian ini di Kota Semarang yang merupakan daerah endemis Leptospirosis yaitu pada 9 kecamatan (Kecamatan Candisari, Gajahmungkur, Gayamsari, Genuk, Pedurungan, Semarang Selatan, Semarang
Timur dan Semarang Utara) terletak di pusat kota, dengan kasus Leptospirosis terjadi setiap tahun (2013-2016) memiliki area yang tidak terlalu luas namun kepadatan penduduknya sangat tinggi. ${ }^{11}$ Rata-rata suhu udara di Kota Semarang 
mencapai $28,43^{\circ} \mathrm{C}$ yang merupakan suhu udara optimal untuk perkembangbiakan bakteri Leptospira ${ }^{12-13}$

Subyek dari penelitian ini terfokus pada pekerja sektor informal yang dibatasi, dikaitkan dengan potensi paparan sumber infeksi Leptospirosis selama subyek penelitian bekerja. Pekerja sektor informal merupakan pekerja-pekerja yang bekerja di sektor yang tidak terlindungi (unprotected sector), akan tetapi orang masuk ke sektor ini relatif bebas (free entry). Adanya 'free entry' membuat sektor informal dibanjiri pekerja yang kurang terdidik dan kurang trampil ataupun tenaga kerja yang tidak bisa atau belum terserap sektor formal. ${ }^{14-15}$ Sektor informal juga merupakan suatu unit usaha dengan pola kegiatan tidak teratur baik waktu, modal, maupun penerimaannya, hampir tidak tersentuh oleh peraturan atau ketentuan dari pemerintah, modal, peralatan dan perlengkapan serta omset yang diperoleh biasanya kecil dan dilakukan oleh masyarakat yang berpenghasilan rendah, tidak membutuhkan keahlian khusus dalam menjalankan kegiatannya, dan pada umumnya satuan usahanya mempekerjakan tenaga kerja yang sedikit dari lingkungan, hubungan keluarga, serta dengan mudah dapat berganti atau beralih keusaha lain. Mereka yang memasuki usaha berskala kecil ini, mulanya bertujuan mencari kesempatan kerja dan menciptakan pendapatan. Kebanyakan dari mereka yang terlibat adalah migran dari golongan miskin, berpendidikan rendah dan kurang terampil. ${ }^{14,16,17}$

\section{Riwayat mendapatkan luka pada saat bekerja}

Hasil analisis menunjukkan bahwa adanya riwayat luka yang didapat selama bekerja berhubungan signifikan terhadap kejadian Leptospirosis, dan membuktikan hipotesis yang menyatakan riwayat mendapatkan luka pada saat bekerja merupakan faktor risiko
Leptospirosis pada pekerja sektor informal. Hasil tersebut sesuai dengan penelitian yang menyebutkan adanya riwayat luka di antara kurun waktu 4 minggu sebelum sakit mempunyai risiko 44,38 kali lebih besar untuk terjadi Leptospirosis dibandingkan yang tidak. ${ }^{18}$ Responden dengan riwayat mengalami luka terbuka ringan di bagian tangan, kaki, muka dan juga ada bagian kaki dan tangan yang membekas seperti bekas terendam air dalam waktu lama. Adanya luka terbuka dapat meningkatkan risiko masuknya bakteri Leptospira ke dalam tubuh pada saat terjadi kontak dengan air, tanah, atau tanaman yang diduga terkontaminasi urin yang mengandung bakteri Leptospira dan atau pada saat terendam banjir ataupun air rob yang diduga terkontaminasi Leptospira. ${ }^{18}$

Apabila dikorelasikan dengan penggunaan APD, sebanyak 87,5\% pekerja sektor informal dengan riwayat luka selama bekerja tidak memakai APD selama bekerja. $67,5 \%$ responden dengan riwayat luka mempunyai riwayat kontak dengan sumber infeksi, dimana riwayat kontak langsung: 17,5\% dengan bangkai tikus, 5\% dengan tikus, 37,5\% dengan air selokan, $50 \%$ dengan genangan air, $53,5 \%$ dengan sampah dan $35 \%$ dengan kotoran tikus. Hal ini mendukung teori konsep kejadian Leptospirosis yang disebutkan oleh WHO, bahwa salah satu cara bakteri Leptospira masuk ke tubuh manusia adalah dengan melalui luka atau lecet pada kulit, sehingga apabila tidak memakai APD maka Leptospira dapat masuk ke tubuh. ${ }^{18-20}$

Hal tersebut didukung juga dengan teori yang menyebutkan bahwa syarat timbulnya infeksi adalah bahwa organisme yang menular harus mampu melekat, menduduki/ memasuki hospes dan berkembang biak paling tidak sampai taraf tertentu. Kulit merupakan batas utama antara lingkungan dan tubuh manusia yang menjadi imunitas non spesifik lapis pertama. Kulit yang utuh memiliki lapisan keratin atau lapisan 
tanduk pada permukaan luar dan epitel berlapis gepeng sebagai barier mekanis yang baik sekali terhadap infeksi. Jasad renik sulit menembus barier mekanis ini, namun apabila terjadi luka iris, abrasi atau maserasi memungkinkan agen menular masuk. $^{21}$ Jika agen berhasil menembus salah satu barier tubuh dan memasuki jaringan, maka pertahanan berikutnya adalah reaksi, yang merupakan respon imun innate, yang diperlihatkan dengan reaksi inflamasi. Jika reaksi peradangan akut tidak sanggup mengatasi penyerang, infeksi menyebar lebih luas ke seluruh tubuh. $^{21}$

Apabila mikroorganisme dapat melewati pertahanan nonspesifik/ innate immunity, maka tubuh akan membentuk mekanisme pertahanan yang lebih kompleks dan spesifik dimana imunitas diperantai antibodi. Mekanisme imunitas spesifik ini terdiri dari imunitas selluler dan humoral. Respon imun spesifik selluler ini terjadi 7 hari setelah masa inokulasi yang terjadi berupa opsonisasi makrofag dan aktifasi netrofi. Sitem imun humoral yaitu produksi antibodi spesifik oleh sel limfosit B (T-dependent dan non T-dependent) dan mekanisme Cell mediated immunity (CMI). Sel limfosit $T$ berperan pada mekanisme imunitas ini melalui produksi sitokin serta jaringan interaksinya dan sel sitotoksik matang di bawah pengaruh interleukin 2 (IL-2) dan interleukin 6 (IL-6). ${ }^{22}$ Respon imun spesifik humoral pada Leptospirosis ditandai dengan terbentuknya antibodi dan beberapa sitokin (IL-6, TNF- $\alpha$ dan transforming growth factor- $\beta 1$ (TGF$\beta 1)$ ), nitrit oxide (NO) dan $\mathrm{H} 2 \mathrm{O} 2$. Berdasarkan antibodi yang diproduksi, dibagi menjadi dua strain, yaitu strain Low (L) dan High (H). Strain $H$ menunjukkan tendensi yang lebih tinggi terhadap respon $T h 2$, dengan produksi antibodi yang lebih besar, lesi jaringan yang lebih luas serta adanya sintesis IL-4. Strain $L$ menunjukkan respon $T h 1$, dengan produksi yang besar dari interferon (IFN), serta aktivasi makrofag. ${ }^{23}$

\section{infeksi}

Riwayat kontak dengan sumber

Hasil analisis statistik menunjukkan bahwa adanya riwayat kontak dengan sumber infeksi berpeluang 56,98 kali lebih besar untuk terkena Leptospirosis dibandingkan pekerja sektor informal tanpa riwayat kontak dengan sumber infeksi. Hubungan yang signifikan ini dapat dijelaskan bahwa salah satu dari jalur infeksi Leptospirosis adalah adanya kontak dengan jaringan binatang yang terinfeksi bakteri Leptospira. Penularan Leptospirosis juga bisa terjadi secara langsung akibat adanya kontak langsung antara manusia (host) dengan urin/ jaringan binatang yang terinfeksi, dan secara tidak langsung akibat adanya kontak antara manusia dengan tanaman, air, tanah yang terkontaminasi urin binatang terinfeksi. ${ }^{18,20}$

Apabila ditelusur, riwayat kontak langsung responden infeksi dibagi menjadi kontak langsung dan tidak langsung. Riwayat kontak langsung dengan sumber infeksi dinyatakan sebesar 13,4\% kontak langsung dengan bangkai tikus $(24,4 \%$ kasus, 2,4\% kontrol), 4,9\% kontak langsung dengan tikus $(7,3 \%$ kasus, 2,4\% kontrol). Tingginya proporsi riwayat kontak langsung dengan sumber infeksi pada kasus yang lebih besar dibandingkan kontrol mendukung pendapat bahwa penularan Leptospirosis pada hewan ke manusia salah satunya melalui kontak langsung. Pada saat manusia memegang jaringan hewan yang diduga terinfeksi bakteri Leptospira maka pada saat itu pula proses masuknya bakteri Leptospira ke dalam tubuh manusia akan dimulai. Jalan masuk bakteri Leptospira melalui pori kulit manusia yang kemudian akan masuk ke dalam aliran darah. Kontak langsung dengan tikus/bangkai tikus/wahana lain yang diduga telah terinfeksi Leptospira merupakan salah satu jalur penularan Leptospirosis dari tikus ke manusia. ${ }^{18}$ 
Sebanyak 26,8\% kontak langsung dengan air selokan, 36,6\%kontak langsung dengan sampah, 25,6\% kontak langsung dengan kotoran tikus. Hal ini berkaitan dengan jalur penularan Leptospirosisis berdasarkan diketahuinya kemungkinan bahwa bakteri Leptospira yang ada dalam ginjal tikus juga dapat menginfeksi manusia pada saat kontak dengan kulit melalui sentuhan secara sengaja maupun tidak sengaja, terinjak, atau terkena cipratan darah atau cairan tubuh tikus yang terinfeksi (kontak langsung) maupun kontak dengan air, tanah, dan tanaman terkontaminasi urin dari hewan yang terinfeksi Leptospira (kontak tidak langsung). ${ }^{(18)}$ Apabila dikorelasikan dengan variabel lain, maka sebanyak $61,4 \%$ responden dengan riwayat kontak dengan sumber infeksi memiliki riwayat luka pada saat bekerja, 95,5\% tidak memakai APD selama bekerja, 54,5\% memiliki perilaku yang buruk dan $79,5 \%$ memiliki kondisi sanitasi tempat kerja yang buruk.

\section{Kategori umur}

Rerata umur responden 52 tahun, umur minimum 29 tahun dan maksimum 81 tahun, Hasil analisis menunjukkan bahwa pekerja Sektor Informal umur dewasa (18-40 tahun) berisiko 42,22 kali lebih besar untuk terkena Leptospirosis dibandingkan umur tua. Hasil tersebut sesuai dengan pernyataan dimana banyak pekerja beralih masuk dan keluar dari pasar tenaga kerja, serta masuk dan keluar pada sektor informal. Kebanyakan pemuda yang tidak memiliki pengalaman atau pendidikan yang diperlukan untuk memperoleh pekerjaan formal, sehingga mereka umumnya memasuki pasar tenaga kerja dengan bekerja secara informal, baik dengan bekerja tanpa bayaran pada usaha keluarga/bekerja sebagai pekerja lepas. ${ }^{24}$

Apabila umur dikaitkan secara spesifik dengan risiko Leptospirosis dan jenis kelamin, maka risiko kelompok umur dewasa (20-59 tahun) lebih tinggi pada laki-laki dibandingkan wanita, dan pada kelompok umur lanjut (>60 tahun) maka risiko laki-laki dan wanita untuk terkena Leptospirosis adalah sama.(25) Pada usia lanjut (geriartri) terjadi degenerasi organ-organ tubuh yang berakibat pada penurunan fungsi organ sehingga kemampuan homeostatis tubuh menurun dan meningkatkan risiko gangguan fisiologis yang bersifat sistemik maupun pathognomonik. ${ }^{3}$ Penurunan fungsi berbagai sistem organ yang berkaitan dengan pertambahan usia juga turut menimbulkan gangguan imunitas. Akhirnya, bersamaan dengan pertambahan usia, kulit akan menjadi tipis dan tidak begitu elastis lagi. Neuropati perifer dan penurunan sensibilitas serta sirkulasi yang menyertainya dapat menimbulkan ulkus statis, dekubitus, ekskoriasi dan gejala luka bakar. Gangguan integritas kulit merupakan faktor predisposisi yang memudahkan orang tua untuk mengalami infeksi mikroorganisme yang merupakan bagian dari flora kulit yang normal. ${ }^{26}$

Sebuah studi Bappenas mendukung kesimpulan diatas, bahwa sektor informal masih memegang peranan penting menampung angkatan kerja, terutama angkatan kerja muda yang masih belum berpengalaman atau angkatan kerja yang pertama kali masuk pasar kerja, yang dapat mempunyai dampak positif mengurangi tingkat pengangguran terbuka, tetapi di sisi lain menunjukkan gejala tingkat produktivitas yang rendah, karena masih menggunakan alat-alat tradisional, tingkat pendidikan dan keterampilan yang relatif rendah. ${ }^{27}$

Hasil diatas juga sesuai dengan penelitian pada sektor informal yang terterdahulu dimana banyak pekerja beralih masuk dan keluar dari pasar tenaga kerja, serta masuk dan keluar pada sektor informal. Kebanyakan pemuda yang tidak memiliki pengalaman atau pendidikan yang diperlukan untuk memperoleh pekerjaan formal, sehingga mereka umumnya memasuki pasar tenaga kerja 
dengan bekerja secara informal, baik dengan bekerja tanpa bayaran pada usaha keluarga atau bekerja sebagai pekerja lepas. Setelah mengumpulkan pengalaman dan aset, para pekerja di usia produktifnya memiliki peluang lebih besar untuk memasuki sektor formal atau menjadi wiraswasta. Sedangkan pekerja diatas 50 tahun mempunyai peluang jauh lebih besar untuk memiliki usaha non-tani sendiri, sebuah keadaan yang mengisyaratkan bahwa beberapa pekerja sektor informal mampu meningkatkan kesejahteraannya sambil tetap di sektor informal. $^{24}$

Sebanyak $64,7 \%$ responden dengan kategori umur 18-40 tahun mempunyai riwayat kontak dengan sumber infeksi; $88,2 \%$ tidak memakai APD selama bekerja; 29,4\% mempunyai riwayat luka saat bekerja; sebanyak 41,2\% memiliki perilaku yang buruk; $70,6 \%$ terdapat tikus di tempat kerja; sebanyak 76,5\% memiliki kondisi sanitasi tempat kerja yang buruk dan sebanyak 52,9\% memiliki kondisi sanitasi rumah yang buruk. Sehingga dalam hal ini, dapat diasumsikan bahwa kondisi pekerja usia dewasa (18-40 tahun) pada sektor informal lebih banyak dan dengan kondisi minim pengalaman dan rendahnya pendidikan sehingga di dukung dengan perilaku yang buruk serta kondisi lingkungan yang berpotensi tinggi menularkan Leptospirosis, sehingga kasus Leptospirosis juga lebih tinggi pada kelompok umur dewasa (1840 tahun) dibandingkan usia tua (> 40 tahun).

\section{Jenis kelamin pekerja sektor informal}

Dari hasil analisis menunjukkan bahwa pekerja sektor informal dengan jenis kelamin laki-laki berpeluang 37,01 kali lebih besar untuk terkena Leptospirosis dibandingkan perempuan. Apabila dikaitkan dengan sistem respon imun pada tubuh manusia, maka dapat dijelaskan bahwa sebelum pubertas, sistem imun pada wanita dan pria adalah sama, berkembang tanpa pengaruh hormon seks. $^{28}$ Kemampuan hormonhormon seks untuk memodulasi imunitas telah diketahui dengan baik. Ada bukti yang menunjukkan bahwa estrogen memodulasi aktivitas limfosit $T$ sementara androgen berfungsi untuk mempertahankan produksi interleukin-2 (IL-2) dan aktivitas sel supresor. Efek hormon seks pada sel-sel B tidak begitu menonjol. Estrogen akan mengaktifkan populasi sel B yang berkaitan dengan autoimun yang mengekspresikan marker CD5 (marker antigenik pada sel B). Estrogen cenderung menggalakkan imunitas sementara androgen bersifat imunosupresif. Umumnya penyakit autoimun lebih sering dijumpai pada wanita ketimbang pada laki-laki ${ }^{26}$

Androgen yang dilepas pria bersifat imunosurpresif, dilepas selama menetap selama masa dewasa dan tidak berfluktuasi sampai usia lanjut. Pada wanita, respon imun terintegrasi dengan sistem endokrin yang tujuannya agar janin dalam kandungan tidak ditolak selama hamil. Wanita mengalami lebih sedikit infeksi selama hidupnya dibanding pria, yang diduga disebabkan oleh efek androgen. Meskipun terjadi penghambatan sel T episodik, wanita tidak menunjukkan infeksi yang lebih sering dibanding pria, juga selama hamil. Hal ini menunjukkan peran besar immunoglobulin terhadap infeksi.(28) Apabila jenis kelamin dikaitkan secara spesifik dengan risiko Leptospirosis dan pada kelompok umur tertentu, maka risiko laki-laki untuk terkena Leptospirosis pada kelompok umur dewasa (20-59 tahun) lebih tinggi pada dibandingkan wanita, dan pada kelompok umur lanjut (>60 tahun) risiko laki-laki dan wanita adalah sama. Hal ini dikaitkan dengan peran dari kromosom "X" yang berjumlah 2 kromosom pada wanita, dimana kromosom " $X$ " ini merepresentasikan beberapa gen yang diimplikasikan pada proses immunologi, seperti Toll-like receptors, multiple 
cytokin receptors, gen pada aktivitas sel-T dan sel-B serta faktor pengaturan transkripsi dan translasi. Sedangkan pada kromosom "Y" berperan pada sejumlah gen pada inflammatory pathways. ${ }^{25}$

Hasil penelitian ini sejalan dengan beberapa penelitian terdahulu yang menyebutkan bahwa berdasarkan jenis kelamin, pekerja yang terpapar sebagian besar pekerja di pedesaan biasanya lakilaki. ${ }^{29}$ Rejeki menyebutkan jenis kelamin responden pada kasus $76,2 \%$ laki-laki $^{30}$ Proporsi kasus yang tinggi pada laki-laki kemungkinan berhubungan dengan pekerjaan, dimana sebagian besar penderita bekerja sebagai petani yang lebih banyak dikerjakan laki-laki, dengan perempuan membantu sewaktu-waktu $(\mathrm{OR}=9,6)$ serta didukung Poeppl ${ }^{32}$ yang menyebutkan bahwa jenis kelamin adalah salah satu faktor kejadian Leptospirosis, dimana paling banyak pada laki-laki umur 18-57 tahun. Dominasi ini dipengaruhi oleh kecenderungan yang lebih besar untuk berpartisipasi dalam kegiatan di luar ruangan sehingga risiko terpapar lebih besar. $^{31-32}$

\section{Sanitasi Rumah}

$\begin{array}{ccc}\text { Hasil analisis } & \text { statistik } \\ \text { menunjukkan bahwa kondisi } & \text { sanitasi } \\ \text { rumah yang buruk (skor } & <60 \% \text { ) }\end{array}$ merupakan faktor risiko kejadian Leptospirosis pada pekerja sektor informal. Kebersihan rumah umumnya berhubungan dengan pengelolaan sampah rumah tangga atau bahan yang tidak digunakan atau terbuang, baik sampah padat (refuse), sampah mudah busuk (garbage), dan sampah tidak mudah busuk (rubbish). Rumah dengan penataan perabotan yang berserakan cenderung kebersihan rumahnya kurang, yang berarti banyak ditemukan sampah dan barangbarang tidak terpakai dirumahnya. Barang yang tidak tertata rapi dapat menjadi tempat persembunyian tikus. ${ }^{33}$ Sebanyak $78 \%$ rumah responden kelompok kasus terdapat sampah didalam rumahnya, untuk kemudian sampah diangkut oleh petugas (56,1\% kelompok kasus) setiap 2x seminggu (36,6\% pada kelompok kasus), $63,4 \%$ responden kelompok kasus terbiasa menyimpan makanan sisa pada malam hari. Sisa makanan dimalam hari merupakan sumber pakan tikus sehingga keberadaan sampah dan sisa makanan pada malam hari meningkatkan kontak dengan tikus. ${ }^{33}$ Hasil penelitian ini juga sejalan dengan penelitian Sarkar yang menyebutkan bahwa kondisi sanitasi tempat tinggal yang buruk dengan adanya kumpulan sampah merupakan faktor risiko kejadian Leptospirosis. ${ }^{34}$

Berkaitan dengan keberadaan tikus, sebanyak $48,78 \%$ responden menyatakan terdapat tikus didalam rumahnya, serta $96,3 \%$ responden pernah melihat tikus didalam dan lingkungan rumahnya. Tikus terutama Rattus Norvegicus merupakan reservoir penting dalam penularan Leptospirosis. ${ }^{35}$ Tikus rumah yang juga dikenal sebagai tikus komensal (commensal rodent atau synanthropic) seluruh aktivitas hidupnya, seperti mencari makan, berlindung, bersarang, dan berkembang biak dilakukan di dalam rumah. Adanya tikus mengindikasikan lingkungan yang tidak sehat. ${ }^{31}$ Keberadaan tikus disekitar rumah ditentukan oleh ketersediaan pakan dan tempatberlindung/bersarang. Keberadaan tikus dilingkungan tempat tinggal meningkatkan potensi penularan Leptospirosis. ${ }^{35}$

Hasil ini sejalan dengan hasil penelitian Priyanto yang menyatakan bahwa rumah yang didalamnya terdapat tikus bersiko terkena Leptospirosis sebesar 5,87x dibandingkan responden yang didalamnya tidak dijumpai tikus serta Sarkar yang menyebutkan bahwa melihat tikus di dalam rumah berisiko 4,5 kali lebih besar untuk terjadi Leptospirosis. Infeksi bakteri Leptospira $s p$. terjadi karena kondisi lingkungan perumahan yang banyak dijumpai tikus. Bakteri Leptospira sp. banyak menyerang tikus besar seperti tikus wirok (Rattus 
norvegicus) dan tikus rumah (Rattus diardii). ${ }^{31,34,35}$

Cara responden mengetahui keberadaan tikus diketahui dengan beberapa cara yaitu dengan melihat tikus secara langsung $(65,9 \%$ kasus, 9,8\% kontrol), melihat tikus dilingkungan sekitar rumah $(82,9 \%$ kasus, 56,1\% kontrol), melihat bekas gigitan tikus (36\% kasus, 0\% kontrol), mendengar suara tikus $(56,1 \%$ kasus, $34,1 \%$ kontrol), mencium bau kotoran (43,9\% kasus, 7,3 kontrol) serta dengan melihat kotoran dan bekas tikus $(51,2 \%$ kasus, $12,2 \%$ kontrol).

Berdasarkan hasil tersebut dapat dilihat bahwa cara identifikasi responden mengenai keberadaan tikus masih terbatas pada kehadiran (melihat tikus secara langsung, mendengar), dan jarang mengetahui jika terdapat tanda tikus yang lain, seperti bau kotoran, kencing tikus, bekas bekas gigitan/keratan tikus pada kain, perabot dan kayu. Pada kelompok kasus, sebanyak $78 \%$ responden memiliki SPAL dengan sistem yang masih terbuka, SPAL berbau $(70,7 \%)$ dan SPAL tidak lancar $(65,9 \%)$. Saluran limbah yang terbuka dan airnya tidak lancar sehingga tergenang dan banyak sampah sangat potensial sebagai tempat bersarangnya tikus, terutama tikus got sebagai pembawa bakteri Leptospira sehingga memperbesar kemungkinan penularan melalui kontak langsung dengan air kotor/air selokan. ${ }^{33}$

\section{Kesimpulan}

Faktor risiko kejadian Leptospirosis pada pekerja sektor informal adalah umur dewasa (18-40 tahun), jenis kelamin laki-laki, riwayat mendapatkan luka selama bekerja, sanitasi rumah yang buruk, dan riwayat kontak dengan sumber infeksi.

Probabilitas terjadinya Leptospirosis pada pekerja sektor informal sebesar $99,942 \%$ pada pekerja sektor informal berusia dewasa (18-40 tahun), berjenis kelamin laki-laki, ada riwayat luka saat bekerja, kondisi sanitasi rumah yang buruk, dan ada riwayat kontak dengan sumber infeksi, sedangkan $0,058 \%$ sisanya disebabkan oleh tingkat pendidikan, perilaku, APD, lama kerja, kondisi sanitasi tempat kerja dan keberadaan tikus ditempat kerja.

\section{Ucapan Terimakasih}

Terimakasih kepada Dinas

Kesehatan Provinsi Jateng, Dinas

Kesehatan Kota Semarang, Dinas Kesbangpolinmas Kota Semarang, Puskesmas Pandanaran, Bandarharjo, Pegandan, Bangetayu, Tlogosari Wetan, Tlogosari Kulon, Halmahera, Candi Lama, Bulu Lor, Kagok, Karangayu, Sekarang, Rowosari, Miroto, Genuk, Lebdosari dan Ngemplak Simongan, yang telah membantu dan memberikan ijin, data dan konsultasi selama proses penelitian.

\section{Daftar Pustaka}

1. WHO, ILS. Human Leptospirosis: Guidance For Diagnosis, Surveillance And Control. WHO Library. 2003;45(5):P.1-109.

2. WHO, FAO, OIE. Leptospirosis Surveillance Report 18. [Internet]. Queensland; 2009 Jan-Dec:P.3-12. Available from: http://www.health.qld.gov.au/qhcss/1 ep_rep.asp

3. Wahyuni, Handayani SA, Susilastuti F, Setijowati H,Mardijanto D, Sugihantono A. Kajian Leptospirosis di Kota Semarang. Makalah Seminar Klinik Leptospirosis Dinas Kesehatan Provinsi Jawa Tengah. Semarang; 2012:P.1-11

4. Dinkes. Leptospirosis. dalam: Buku Saku Kesehatan Triwulan I Tahun 2014. Semarang: Dinkesprop Jateng; 2014:P.30-31.

5. Kementrian Kesehatan. Leptospirosis in Profil Kesehatan Indonesia 2012 [Internet]. Jakarta: 
Kementerian Kesehatan Republik Indonesia; 2012:P.108-111. Available from: http://www.kemkes.go.id

6. Kementrian Kesehatan. Profil Kesehatan Indonesia Tahun 2013 [Internet]. Jakarta:Kementerian Kesehatan RI. 2014:P.507. Available from:

http://scholar.google.com/scholar?hl $=$ en\&btnG=Search\&q=intitle:Profil+ Data+Kesehatan+Indo nesia+Tahun+2011\#0

7. Dinkes Kota Semarang. Profil Kesehatan Kota Semarang 2014. Semarang: Dinkes Kota Semarang; 2015:P.52-55.

8. Kuemba LS. Buruh Bagasi Kapal di Pelabuhan Kota Bitung. P.1-11

9. Susila S. Metodologi Penelitian Retrospective/Ex post facto, Case Control Causal Correlation. Boss Script; 2015:P.10-35.

10. Kleinbaum DG. Logistic Regression, A Self Learning Text. New York: Springer-Verlag New York, Inc; 2002.P.2-30.

11. BPS. Statistik Kesejahteraan Sosial Kota Semarang 2015. 2015:P10-16.

12. Nugroho A. Analisis Faktor Lingkungan dalam Kejadian Leptospirosis di Kabupaten Tulungagung. BALABA. Vol.11(No.2):P.73-80.

13. BPS. Statistik Daerah Kota Semarang 2016. 2016:P10-15.

14. Indrawan T.A. Hubungan Sektor Informal Dengan Kesempatan Kerja dan Kesempatan Menyekolahkan Anak (Studi Sektor Informal di Pinggir Jalan Ki Hajardewantoro Belakang Kampus Kentingan Universitas Sebelas Maret Surakarta. Fakultas Keguruan dan Ilmu

15. Ra. Leisa Triana. Soman Wisnu Darm. Dimensi Pekerja Informal Sulawesi Barat. BPS Sulawesi Barat; 2014:P.1-3.

16. Arung L. Kondisi Sektor Informal Perkotaan dalam Perekonomian
Jayapura-Papua. Jurnal Ekonomi Bisnis. 2011;2(16):P.155-60.

17. Hakim L. Perkembangan Tenaga Kerja Wanita Di Sektor Informal: Hasil Analisa Dan Proxy Data Sensus Penduduk. Among Makarti. 2011;4(7):P.20-32.

18. Menteri Pertanian. Surat Keputusan Menteri No.555/Kpts/TN.240/9/1995,

Tentang Syarat-Syarat Rumah Pemotongan Hewan.

19. Kemenkes RI. Petunjuk Teknis Upaya Pengendalian dan Penanggulangan Kejadian Luar Biasa (KLB). Jakarta: Bakti Husada; 2013:P.13-18.

20. Kusmiyati, Noor SM, Supar. Animal and Human Leptospirosis in Indonesia. Wartazoa. 2005;15(4):P.213-9.

21. Wilson SAPLM. Patofisiologi. Konsep Klinis Proses-Proses Penyakit. Edisi ke E. Penerbit Buku Kedokteran EGC:P.82-83.

22. Resti M. Sistem imun [Internet]. 2012. Available from:http://marsellyresti.blogspot.co.i d/2012/10/sistem-imun.html.

23. Kerang Ijo. Leptospirosis [Internet]. https://kerangijo.wordpress.com/2011 /01/19/leptospirosis/. [cited 2016 Jun 24]. Available from: https://kerangijo.wordpress.com/2011 /01/19/leptospirosis/.

24. ILO. Indonesia: Tren Sosial dan Ketenagakerjaan Agustus 2014. Asian Decent Work Decade 20152016. Jakarta; 2015:P.1-4. Available from: www.ilo.org/jakarta

25. Carmen Giefing-Kroll, Peter Berger, Gunter Lepperdinger, Beatrix Grubeck-Loebenstein. Review: How Sex and Age Affect Immune Responses, Susceptibility to Infections, and Response to Vaccination. Institute For Biomedical Aging Research of Innbruck University. Innbruck, Austria. DOI: 10.1111/acel.12326. Published by the 
Anatomical Society and John Willey and Sons, Ltd. 2015.14.P.309-321.

26. Basrie S. Mekanisme Respon Imun. [Internet]. Available from: http://biologijie.blogspot.co.id/2014/1 1/mekanisme-respon-imun.html]

27. Direktorat Ketenagakerjaan dan Analisis Ekonomi. Studi Profil Pekerja di Sektor Informal dan Arah Kebijakan ke Depan. Jakarta; 2002:P.1-18.

28. Baratawidjaja KG. Immunologi Dasar. Edisi ke-7. UI FK, editor. Jakarta: Balai Penerbit FKUI; 2006:P.131-135.

29. Faine S. Guidelines for the control of leptospirosis. WHO offset publication. 1982:P. 1-171.

30. Rejeki DSS. Faktor Risiko Lingkungan Yang Berpengaruh Terhadap Kejadian Leptospirosis Berat. [Thesis]. Semarang: Undip; 2005:P.1-129.

31. Ramadhani T, Yunianto B. Reservoir dan Kasus Leptospirosis di Wilayah Kejadian Luar Biasa Reservoir and Case of Leptospirosis in Outbreak Area. Kesehatan Masyarakat Nasional. 2011;7(4):P.162-8.
32. Paeppl W. High Prevalence of Antibodies Against Leptospira Spp. In Male Austrians Adults: a Crosssectional Survey. 2009:P.23-27.

33. Ramadhani T, Yunianto B. Kondisi Lingkungan Pemukiman yang Tidak Sehat Berisiko terhadap Kejadian Leptospirosis (Studi Kasus di Kota Semarang). Suplemen Media Penelitian dan Pengembangan Kesehatan. 2010;XX:P.46-54.

34. Sarkar U., Nascimento SF., Barbosa R., Martins R., Nuevo H., Kalafanos I. E al. Population-Based CaseControl Investigation Of Risk Factors For Leptospirosis During An Urban Epidemic. American Journal of Tropical Medicine Hygiene. 2002:P.605-10.

35. Priyanto A, Hadisaputro S, Santoso L, Gasem HSA. Faktor-Faktor Risiko Yang Berpengaruh Terhadap Kejadian Leptospirosis (Studi Kasus di Kabupaten Demak). [Thesis]. Semarang : Undip; 2008:P.1-11. 